\title{
Ethnobotany of indigenous (Traditional) vegetables in Adi tribe of East Siang region of Arunachal Pradesh, India
}

\author{
Md. Ramjan 四 \\ College of Horticulture and Forestry, Central Agricultural University, Pasighat, Arunachal Pradesh, India. \\ Chandra Deo \\ College of Horticulture and Forestry, Central Agricultural University, Pasighat, Arunachal Pradesh, India. \\ L. Wangchu \\ College of Horticulture and Forestry, Central Agricultural University, Pasighat, Arunachal Pradesh, India. \\ P. Sarma \\ College of Horticulture and Forestry, Central Agricultural University, Pasighat, Arunachal Pradesh, India. \\ Amit Kumar Singh \\ College of Horticulture and Forestry, Central Agricultural University, Pasighat, Arunachal Pradesh, India. \\ Shivani Dobhal \\ College of Horticulture and Forestry, Central Agricultural University, Pasighat, Arunachal Pradesh, India.
}

\begin{tabular}{|c|c|}
\hline ARTICLE INFO & ABSTRACT \\
\hline $\begin{array}{l}\text { Received : } 29 \text { June } 2021 \\
\text { Revised : } 14 \text { September } 2021 \\
\text { Accepted : } 24 \text { September } 2021 \\
\text { Available online: } 19 \text { December } 2021 \\
\text { Key Words: } \\
\text { Arunachal Pradesh } \\
\text { Adi tribe } \\
\text { East Siang } \\
\text { Ethanobotany } \\
\text { Traditional Vegetables }\end{array}$ & $\begin{array}{l}\text { Arunachal Pradesh is known as land of rising Sun which is the biggest in terms } \\
\text { of area-wise amongst the state of north east India.The region has } 26 \text { major } \\
\text { tribe; each tribe has its own enormous indigenous knowledge on the uses of } \\
\text { wild plants. Among the tribe, Adi community is one of the major tribe inhabited } \\
\text { in the region which has its own habitual way of using horticultural (vegetables) } \\
\text { resources for sustaining livelihood. Most of the plants are also ethnically } \\
\text { important without wich diverse rituals and festivals (Solung) of adi community } \\
\text { remain unfinished. The current servey was under taken interviewed through } \\
\text { planned questionaire. In our investigation among } 25 \text { wild species, } 5 \text { species } \\
\text { belong to the Solanaceae family which was found to be most widely used family } \\
\text { followed by Apiaceae, Rutaceae, Urticaceae and Araceae. Investigation on the } \\
\text { basis of plant parts used reveals that the edible parts of the plants such as } 6 \\
\text { species found to be widely used though leaves followed by } 3 \text { species fruits and } 3 \\
\text { species whole plants besides these other plant parts like young tender leaves, } \\
\text { tender stalks, petioles, rhizome also has been observed. This study is aim to } \\
\text { initiated the basic information of these valuable herbs vegetable species for } \\
\text { popularizing in future. These can compete with the best vegetables if } \\
\text { appropriate study is initiated for production and ethanomedicine improvement. }\end{array}$ \\
\hline
\end{tabular}

\section{Introduction}

Northeastern states of India generally comprised of Arunachal Pradesh, Assam, Manipur, Meghalaya, Mizoram, Nagaland, Sikkim and Tripura among thses Arunachal Pradesh is the largest in terms of area. The Arunachal Pradesh generally inhabited by 26 main tribes and over 100 sub-tribes. Adiis foremost tribes in the district and consists of 14 sub-communities, which are Shimong and Tangam Panggi, Pailibo, Ramo Millang, Pasi, Padam, Panggi, Pailibo, Ramo Ashing, Bori, Bokar, Karko, spoken by the community belongs to TibetoBurmanlanguage. Adi people celebrated iversefestivals which are crucial parts of their socio-cultural life. Festivals are a sign of the society, costume and life style of the people. The festivals are primarily celebrated for feast, good crop harvest, happiness and for narrating the tradition, myths, folklores and mythologies (Modi, 2007). Arunachal Pradesh is the $12^{\text {th }}$ mega biodiversity region of the world which is a part of Komkar, Minyong, Millang etc. The Adi tongue Indo-Burma region as well as Himalaya

Corresponding author E-mail: mohammadramjan165@gmail.com

Doi: https://doi.org/10.36953/ECJ.2021.22335

This work is licensed under Attribution-Non Commercial 4.0 International (CC BY-NC 4.0)

(C) ASEA 
biodiversity hotspot in world wide (Agarwal, 1999). It has a very rich reservoir of plant diversity. The wild edible species can be utilized for the improvement of new crops through selection, domestication and also capable to assistance in modern agriculture by providing crop breeders with a broad gene pool of potentially useful for crop development (Pandey, 2008). It lies between $26030^{\prime} \mathrm{N}$ and $29030^{\prime} \mathrm{N}$ latitude, with $91031^{\prime} \mathrm{E}$ and 97030 'E longtitude. It covers an area of $83,743 \mathrm{sq}$. $\mathrm{km}$, out of which 67,410 sq. $\mathrm{km}$ area is covered with jungle (FSI, 2011). The state has various physiographies ranges from plants, foot hills and mountains with associated valleys (Dhar, 2004).

The Arunachal Pradesh falls underneath the Himalaya Biodiversity Hotspot and harbor a rich diversity of flora and fauna. Most of the community are still depend on the natural bioresources for their life sustain and occupation (Sarmah, 2010; Srivastava, 2009). As the state harbor international biodersity it has a great possible for ethnobotany studies (Tiwari et al., 1979).

The state receives heavy precipitaion of about 2,000 to 4, $100 \mathrm{~mm}$ annually, mostly from May to September. The mountains slopes and foothills are generally coverd amid alpine, temperate, and subtropical forest. East Siang is one of the districts which are dominated by the Adi tribe. In the tribal society the use of plants as vegetable in dialy diet with medicinal values is well known since early days. They used different plant species in the treatment of various diseases using the various parts of the vegetables like, roots, stems leaves, flowers, fruits, tubers rhizomes etc. of the plant (Mibang et al., 2003). The Adi people has own way of intake raw tender leaves, fruits, inflorescences, tender stem, petiols, stalks and other palnts parts as vegetable in their diet since time immemorial. These plants are consideration of having folk medicinal properties. Raw plant's parts are used with their local prepration alongside meat and fish. This custom of ingestion raw plants parts is handed down from generation to generation and belived that they obtain direct therapeutic advantage by this mode of eating. Besides used in raw of consumption, others parts are also used in cooking. These plants are used as folk medicine, juice, after boiling, crushing, direct application etc. (Jain et al.,1999).
According to Food and Agriculture Organization report, over one billion populations are taking undomesticated plant as their daily diet (Burlingame, 2000). The people have accumulated knowledge about the different edible wild plants and their uses from their ancestors (Sundriyal and Sundriyal, 2004). Untamed edible species offer staple foodstuff for the local inhabitants and hand out as complementry food for non-local communities (Gemedo-Dalle et al., 2005). Many studies have revealed that natural edible plants having good possible supply of nutrition and in several cases they are found to be more nourishing than conventional food crops (Grivetti, 2000).

\section{Material and Methods}

During 2019-2020, the investigation was carried out at various places of East Siang district of Arunachal Pradesh by regular observation on the indigenous edible plants being sold in the markets. Survey was done in different villages namely, Mebo, Bodak, Silluk, Ayeng, Takilalung and Rani Figure 1.

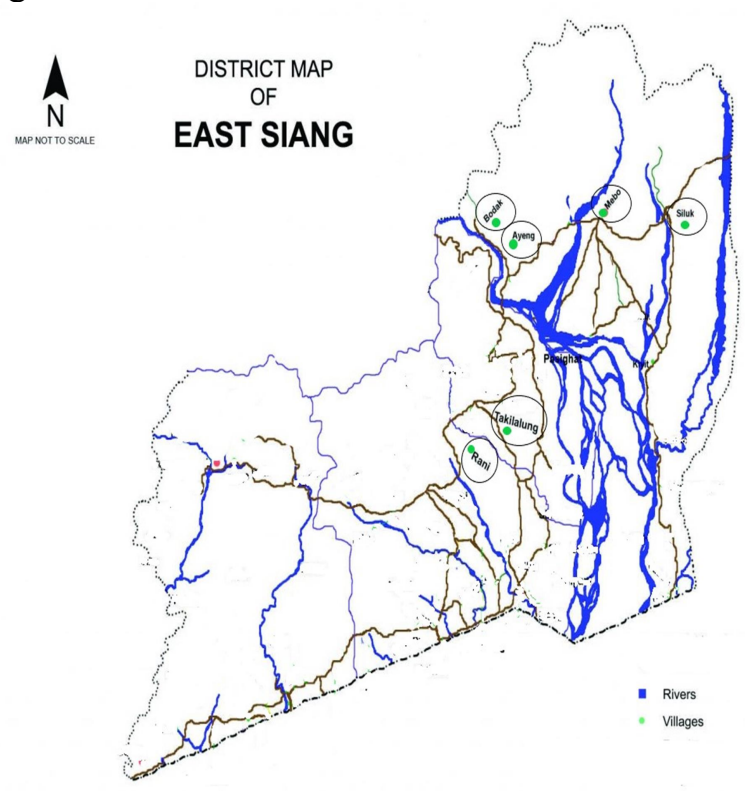

\section{Figure 1: Location map of study area}

Contacts with the local peoples in villages were made to recognize the different plant parts used as remedy and daily diet., Botanical name, Adi name, family, growth habit, plant parts used and Ethanobotany/Traditional uses against a range of ailments were recorded by using Microsoft excel sheet to categorize the category of plants parts used 
in food and medicines. After 2-3 years of surveying following mentioned ethno-vegetable plants are sold frequently in the markets and had made a presence felt.The identification of plant specimens was done by various available literature viz. Deb and Dutta (1971), Chuahan et al. (1996) and Haridasan and Rao (1985-87). Hooker (1872-97), Kanjilal et al., (1930-34), Panigrahi and Joseph (1966), Traditional ethnobotanical and floristic methods of Jain \& Rao (1977) were used. Random plant species were collected and mounted herbarium were prepared, the species were then matched at the herbarium of the BSI, for further proper recognitionand authentication. The identified species are deposited at the Department of vegetable Science, Central Agriculture University, Pasighat, Arunachal Pradesh for future reference.

\section{Results and Discussion}

In the ethnobotanical study reveals the uses of 25 different wild species which is generally belong to different genera and families are used by the peoples of Adi tribe of in this region which is consumed as raw or as cooked and which they believed to have many medicinal benefits (Table1 and Figure 2).

Table1: Wild edible species used by Adi community alive in, East Siang district of Arunachal Pradesh, India

\begin{tabular}{|c|c|c|c|c|c|c|}
\hline $\mathbf{S N}$ & Botanical name & Adi name & Family & Habit & $\begin{array}{l}\text { Parts } \\
\text { used }\end{array}$ & Ethanobotany/Traditional Uses \\
\hline 1 & Diplazium esculentum & Takang & Athyriaceae & Herb & $\begin{array}{l}\text { Tender } \\
\text { leaves } \\
\text { shoots }\end{array}$ & $\begin{array}{l}\text { Boiled young shoots \& leaves are taken } \\
\text { with boiled rice as vegetable for lactative }\end{array}$ \\
\hline 2 & Centella asiatica & Kipum & Apiaceae & Herb & $\begin{array}{l}\text { Whole } \\
\text { plant }\end{array}$ & $\begin{array}{l}\text { Fresh whole plant extract is taken } 2-3 \text { times } \\
\text { a day as stomachic }\end{array}$ \\
\hline 3 & Begoniya josephii & $\begin{array}{l}\text { Sisi } \\
\text { baying }\end{array}$ & Begoniaceae & Herb & $\begin{array}{l}\text { Shoots } \\
\text { leaves }\end{array}$ & $\begin{array}{l}\& \text { Paste of shoots \& leaves is given } 2-3 \text { times } \\
\text { a day for antidysentric }\end{array}$ \\
\hline 4 & Chenopodium album & Gilimili & Chenopodiacea & Herb & $\begin{array}{l}\text { Leaves } \\
\text { young } \\
\text { shoots }\end{array}$ & $\begin{array}{l}\& \mid \text { The leaves \& young shoots may be eaten as } \\
\text { a leaf vegetable, either steamed in its } \\
\text { entirely, or cooked like spinach }\end{array}$ \\
\hline 5 & $\begin{array}{l}\text { Clerodendrum } \\
\text { colebrookiamum }\end{array}$ & Ongin & Verbanaceae & Shrub & Leaves & $\begin{array}{l}\text { Tender leaves are taken as vegetable to } \\
\text { check blood pressure }\end{array}$ \\
\hline 6 & Eryngium foetidum & Adiori & Apiaceae & Herb & Leaves & $\begin{array}{l}\text { Leaves are taken as chutney (condiments) } \\
\text { belived to be appetizer. Paste from stem } \\
\text { and leaf is applied togather on forehead as a } \\
\text { remedy for headache }\end{array}$ \\
\hline 7 & Houttuynia cordata & Roram & saurururaceae & Herb & shoots & $\begin{array}{l}\text { Extract of tender shoot is given for } \\
\text { stomachache. Warmed leaves are packed in } \\
\text { banana leaf foe snuff or massage to get } \\
\text { from sinusities }\end{array}$ \\
\hline 8 & $\begin{array}{l}\text { Mussaendra } \\
\text { roxburghii }\end{array}$ & Akshap & Rubiaceae & Shrub & Leaves & Leaves are cooked and served as vegetable \\
\hline 9. & Physalis minima & Bodopatti & Solanaceae & Herb & Fruit & $\begin{array}{l}\text { Fruit extract is administrated for gasteric } \\
\text { problem }\end{array}$ \\
\hline 10. & Portula caoleracea & $\begin{array}{l}\text { Guberoyi } \\
\text { ng }\end{array}$ & Portulaceae & Herb & $\begin{array}{l}\text { Stem } \\
\text { leaves }\end{array}$ & $\begin{array}{l}\& \text { Stem \& leaves are takien as vegetable witn } \\
\text { boiled rice for stomachic }\end{array}$ \\
\hline 11. & Solanum nigrum & Kopir & Solanaceae & Herb & $\begin{array}{l}\text { Stem, } \\
\text { leaves } \\
\text { berries }\end{array}$ & $\& \mid \begin{array}{l}\text { Stem and tender leaves consumed as } \\
\text { vegetable and considered digestive and } \\
\text { liver stimulent. } \\
\text { Berries are also eaten as raw or as cooked }\end{array}$ \\
\hline
\end{tabular}




\begin{tabular}{|c|c|c|c|c|c|c|}
\hline 12. & Solanum torvum & Kopir & Solanaceae & Shrub & Fruit & $\begin{array}{l}\text { Berry is taken as raw as well as in cooked } \\
\text { form. Good for cough and tonsillitis. }\end{array}$ \\
\hline 13. & Solanum spirale & Okobang & Solanaceae & Shrub & $\begin{array}{l}\text { Leaves } \\
\text { fruit }\end{array}$ & $\begin{array}{l}\text { Tender leaves used as stomach disorder, } \\
\text { warm decoction of fruits is used in } \\
\text { stomache and also as vegetable, chutney } \\
\text { and salad }\end{array}$ \\
\hline 14. & $\begin{array}{l}\text { Solanum } \\
\text { xanthocarpum }\end{array}$ & kopir & Solanaceae & Shrub & Fruit & $\begin{array}{l}\text { Expectorant, tooth-ache, cough, cold, } \\
\text { respiratory problems }\end{array}$ \\
\hline 15. & Spilanthus acmella & Marshang & compositae & Herb & $\begin{array}{l}\text { Leaves } \\
\text { flowers }\end{array}$ & $\& \mathrm{Flc}$ \\
\hline 16. & Zanthoxylun & Ombe & Rutaceae & Tree & $\begin{array}{l}\text { Leaves } \\
\text { fruits }\end{array}$ & $\begin{array}{l}\text { \& Fruits are crushed made into paste solution } \\
\text { to prevent malaria }\end{array}$ \\
\hline 17. & Zanthoxyl umrhetsa & Onger & Rutaceae & Tree & Leaves & $\begin{array}{l}\text { Leaves are eaten as vegetable,blend of seed } \\
\text { mix with allium sativum and slightsalt is } \\
\text { prescribe incase ofabdomenbloating\& used } \\
\text { as hair cleaning agent }\end{array}$ \\
\hline 18. & Sida acuta & Holap & Malvaceae & Herb & $\begin{array}{l}\text { Tender } \\
\text { leaves }\end{array}$ & $\begin{array}{l}\text { Tender are leaves are cooked and eaten as } \\
\text { vegetable to improve }\end{array}$ \\
\hline 19. & Pouzolziaviminea & Oyik & Urticaceae & Herb & Leaves & $\begin{array}{l}\text { Is eaten as vegetable and it is considered by } \\
\text { Adi tribe to increase lactation in women }\end{array}$ \\
\hline 20. & Pouzolzia hirta & $\begin{array}{l}\text { Oyik (big } \\
\text { leaf) }\end{array}$ & Urticaceae & Herb & Leaves & $\begin{array}{l}\text { Is eaten as vegetable and it is considered by } \\
\text { Adi tribe to increase lactation in women }\end{array}$ \\
\hline 21. & Oxalis corneculta & Phakep & oxalidaceae & Herb & $\begin{array}{l}\text { Whole } \\
\text { plant }\end{array}$ & $\begin{array}{l}\text { Whole plant is taken as vegetable, as ant } \\
\text { dysentric and to relive intoxication from } \\
\text { wine }\end{array}$ \\
\hline 22. & Alocasiama corrhiza & Engee & Araceae & Shrub & Rhizome & Pain reliver from insect bite \\
\hline 23. & Alpiniamal accensis & Pupure & Zingiberaceae & Shrub & Rhizome & $\begin{array}{l}\text { A piece of fresh rhizome is taken as } \\
\text { anthelmetic }\end{array}$ \\
\hline 24. & Calamus erectus & Tara & Arecaceae & Tree & $\begin{array}{l}\text { Seed } \\
\text { tender } \\
\text { shoot }\end{array}$ & $\begin{array}{l}\& \text { Fresh seed are taken as dyspepsia. Tender } \\
\text { shoot are taken as vegetable and } \\
\text { anthehelmentic }\end{array}$ \\
\hline 25. & Drymaria cordata & Tayitoar & Caryophyllacea & a Herb & $\begin{array}{l}\text { Whole } \\
\text { plant }\end{array}$ & $\begin{array}{l}\text { Fresh whole plant mixedwith guava is taken } \\
\text { in gastric }\end{array}$ \\
\hline
\end{tabular}

In the investigation of 25 species 5 species belong to the Solanaceae family which was found to be most widely used family followed by Apiaceae, Rutaceae, Urticaceae and Araceae Figure 3 . Investigation on the basis of plant parts used reveals that the edible parts of the plants such as 6 species found to be widely used though leaves followed by 3 species fruits and 3 species whole plants besides these other plant parts like young tender leaves, tender stalks, petioles, rhizome also has been observed Figure 4. The trust behind this form of intake is excellent for fitness and acts as a medication for a variety of disease ailments. This might be recognized due to the presence of various phytochemical compositions in these wild species that boost the power of protection for human body (Benny et al. 2004, Craig 1999). The data on plant parts used reflects leaves are favorite and broadly used parts 6 species were identified, whereas fruits and whole plants comes to the next slot. In our investigation random inspection implies that peoples are well-off in traditional comprehension but to some extent meager in ethno medicinal knowledg. Further servey observed that 16 species belongs to herbs, 7 species from shrub and 3 species from trees Figure 4. As we know uncooked plant foodstuff are considered to be rich in nutrition composition like, carbohydrates, protien, fibre etc. and energy as well as low in calories when compared to cook. These are further rich in various 
vitamins and phytochemical like, ascorbic acid, people are more as compared to the urban and city vitamin A, Riboflavin, tocopherol, carotenoids, dwellers might be due to the fact that daily physical favonoid, terpenods, alkaloids, folatesas well as work combined with all these medicinal doses they various minerals like calcium, magnesium, took everyday as vegetables. The daily intake of selenaium, phosphorus, potassium, zink, boron etc. Further proper documentaion and domestication is needed to assess the scientific and medicinal properties of these plants. It may be hypothesized herbal medicine in the form of vegetables might be one of the imortant reasons for the life longevity and less occurrence of the developed world killer ailments like cancer, diabetes, heart diseases. that the longevity of life in rural and forest dwelling

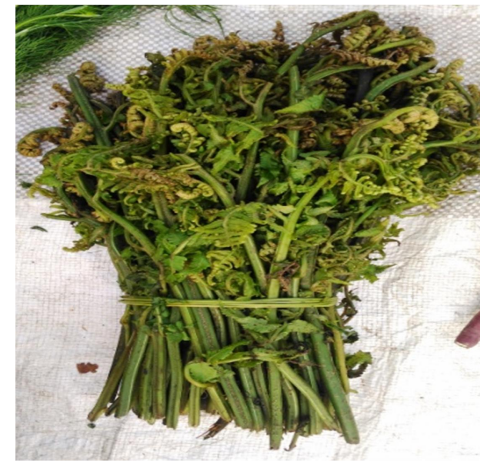

Figure 2a: Diplazium esculentum (Takang)

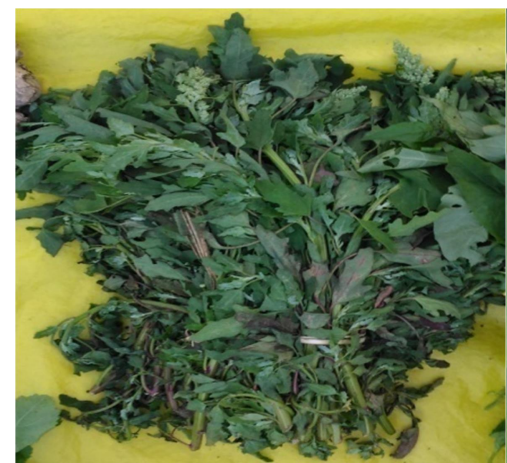

Figure 2d: Chenopodium album (Gilimili)

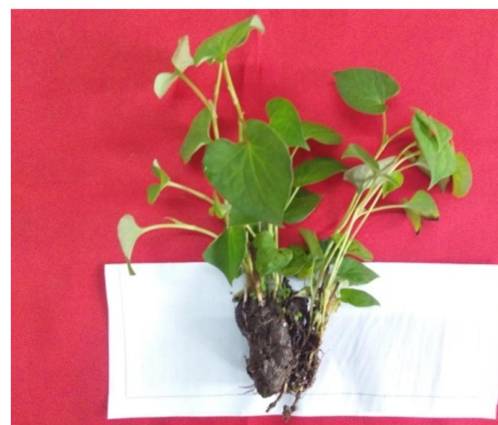

Figure 2g: Houttuynia cordata (Roram)

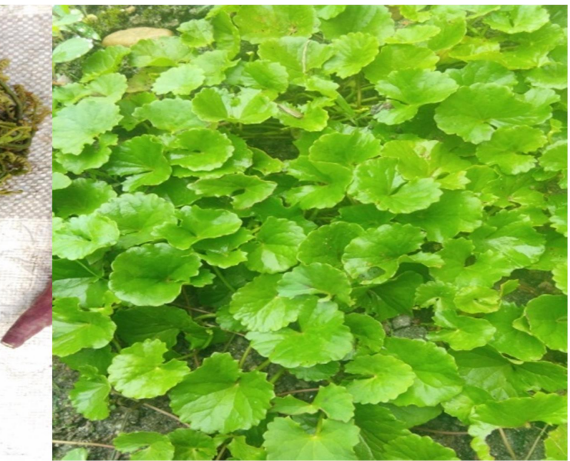

Figure 2b: Centella asiatica (Kipum)

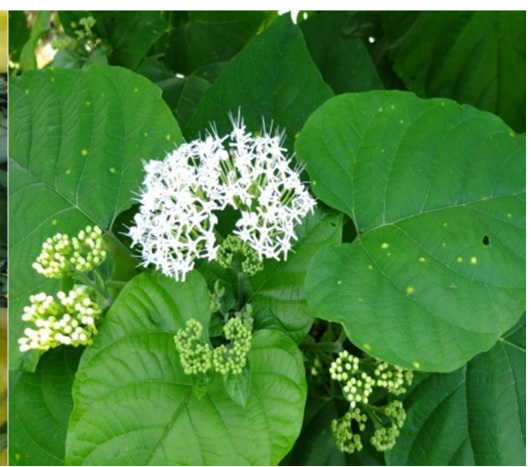

Figure 2e: Clerodendrum colebrookiamum (Ongin)

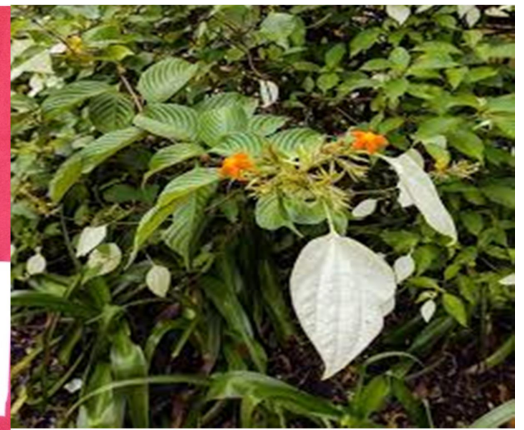

Figure 2h: Mussaendra roxburghii (Akshap)

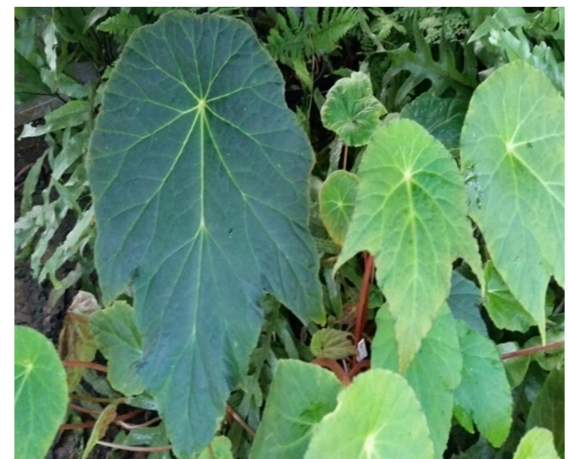

Figure 2c: Begoniya josephii (Sisi baying)
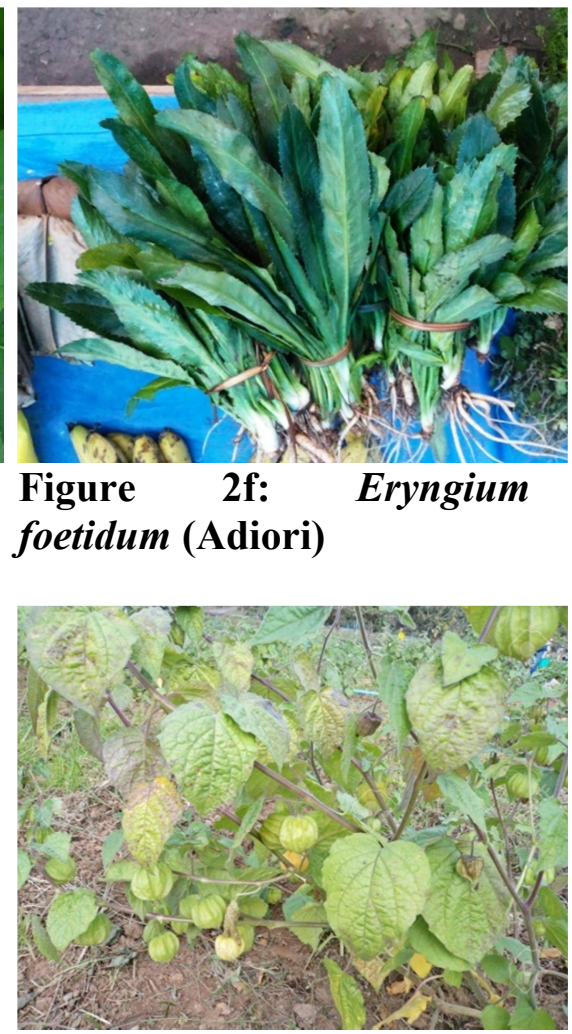

Figure 2i: Physalis minima

(Bodopatti) 


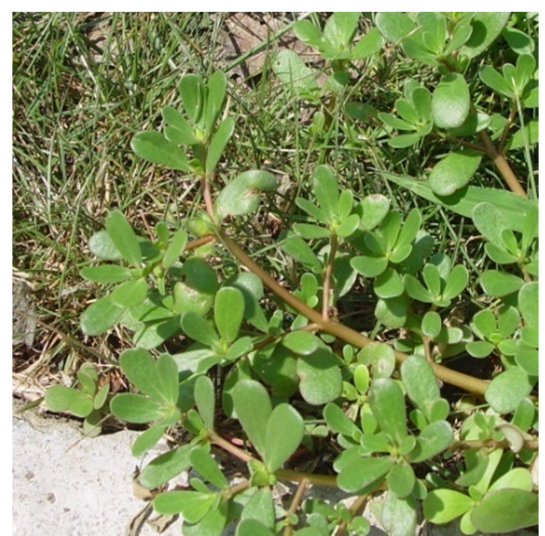

Figure 2j: Portula caoleracea (Guberoying)

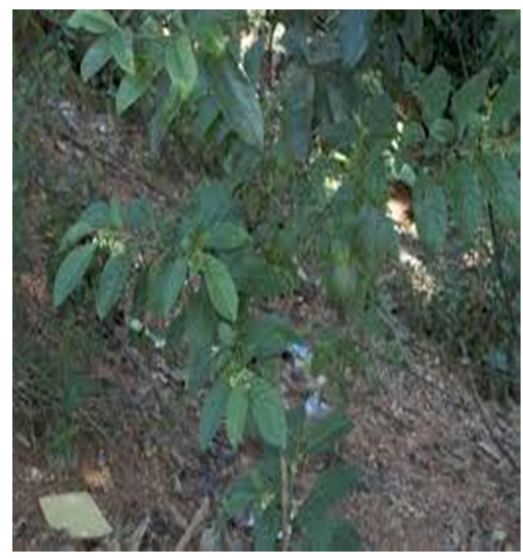

Figure 2m: Solanum spirale (Okobang)

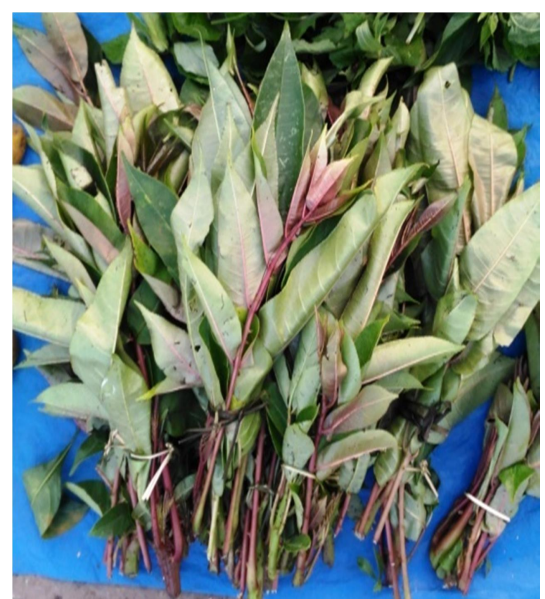

Figure 2p: Zanthoxyl umrhetsa (Onger)

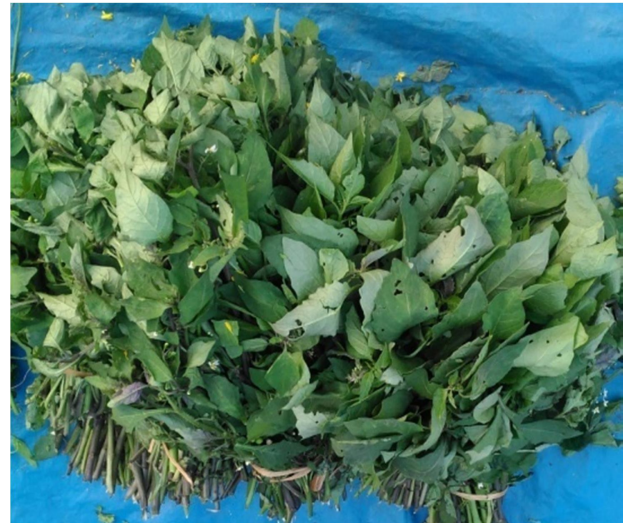

Figure 2k: Solanum nigrum (Kopir)
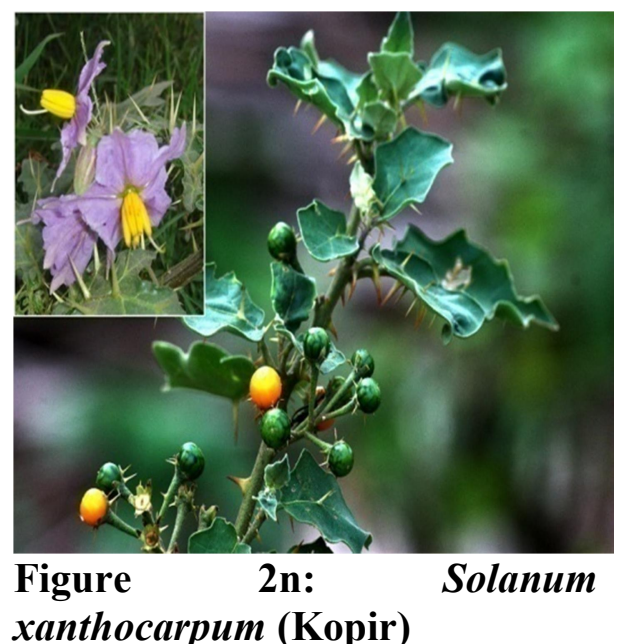

xanthocarpum (Kopir)

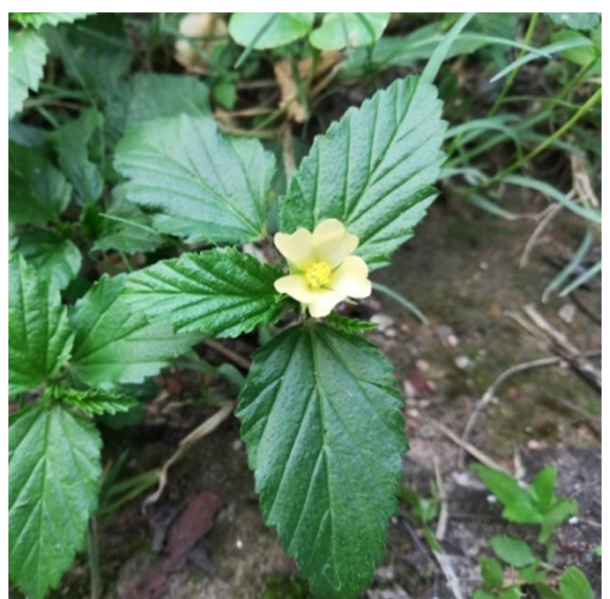

Figure 2q: Sida acuta (Holap)

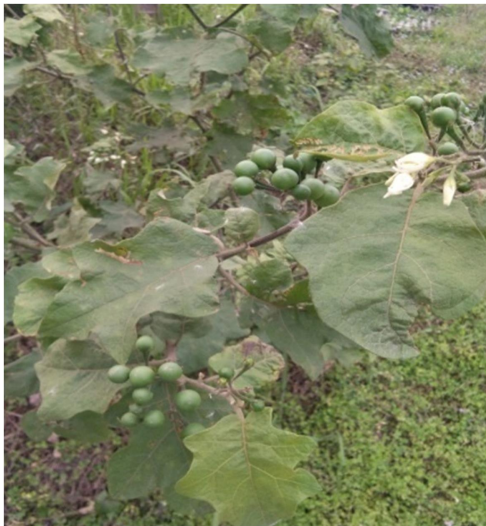

Figure 21: Solanum torvum (Kopir)

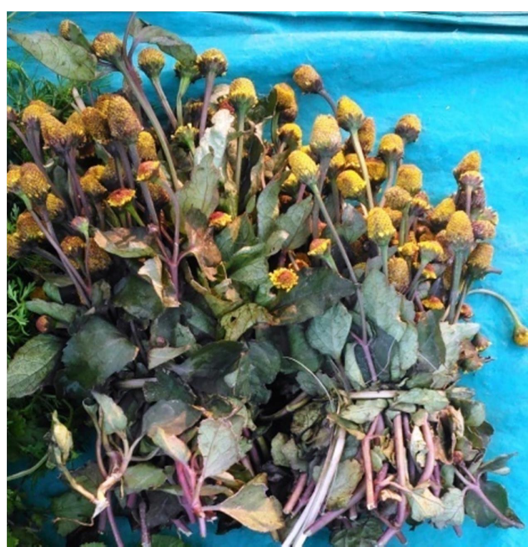

Figure 2o: Spilanthus acmella (Marshang)

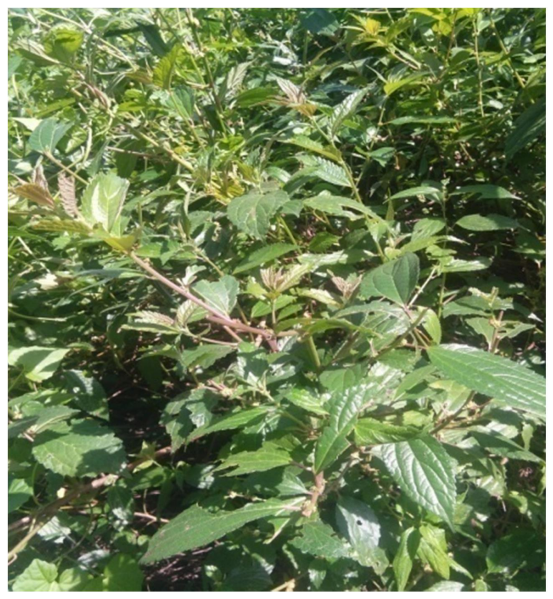

Figure 2r: Pouzolzia hirta (Oyik, big leaf) 


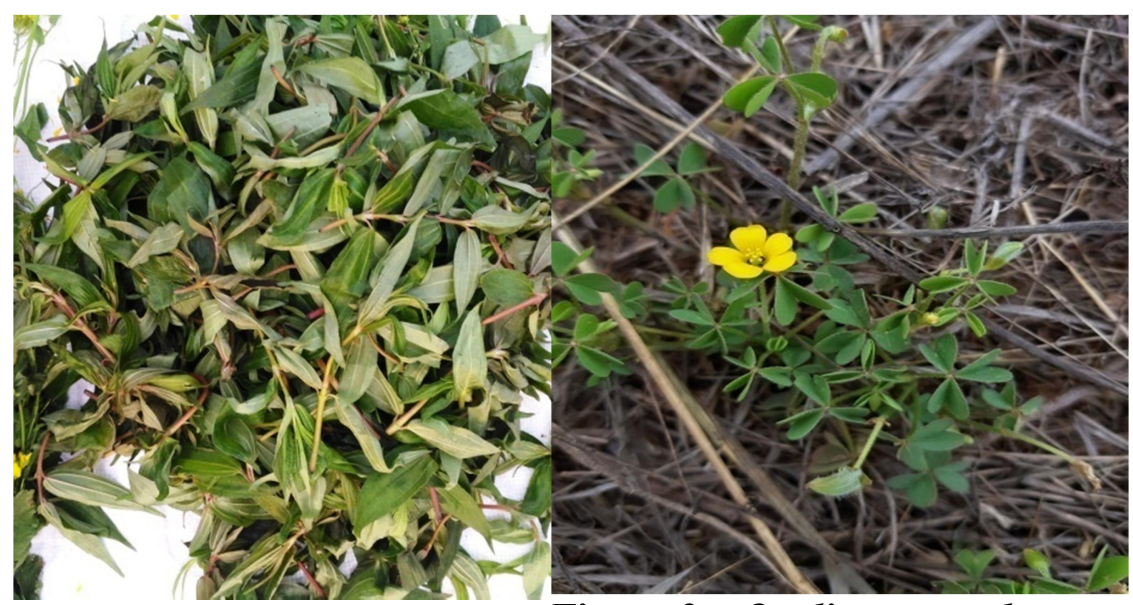

Figure 2s: Pouzolzia Figure 2t: Oxalis corneculta viminea (Oyik, small lef)
(Phakep)

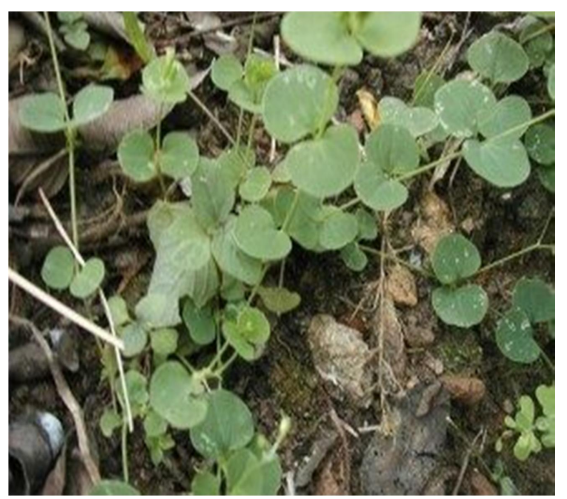

Figure 2v: Drymaria cordata (Tayitoar)
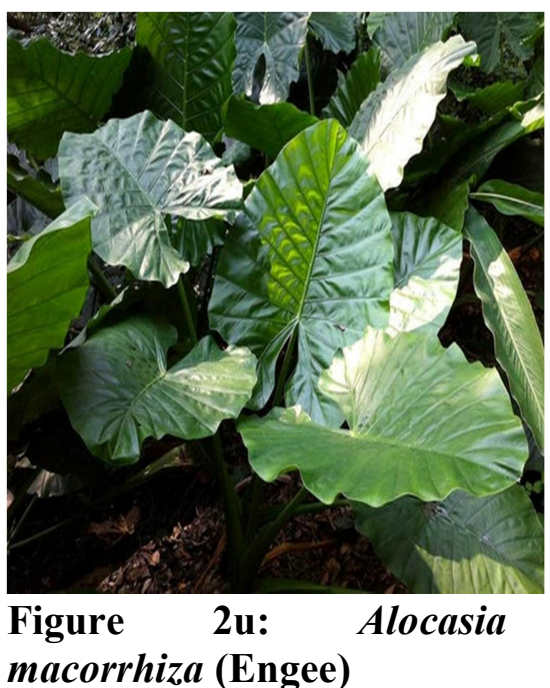

Figure 2: Glimpse of indigenous vegetable used by Adi community in East Siang district

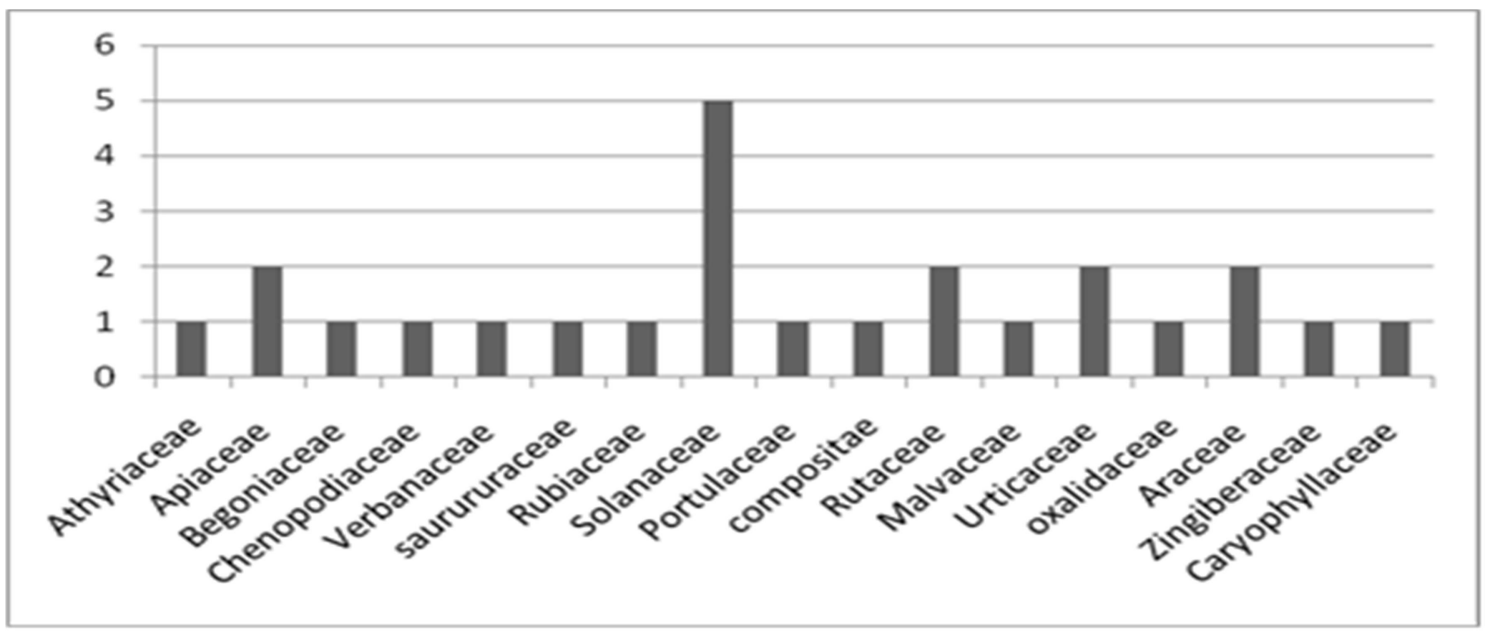

Figure 3: Graphical reprasentation of family dominance in traditional vegetables 


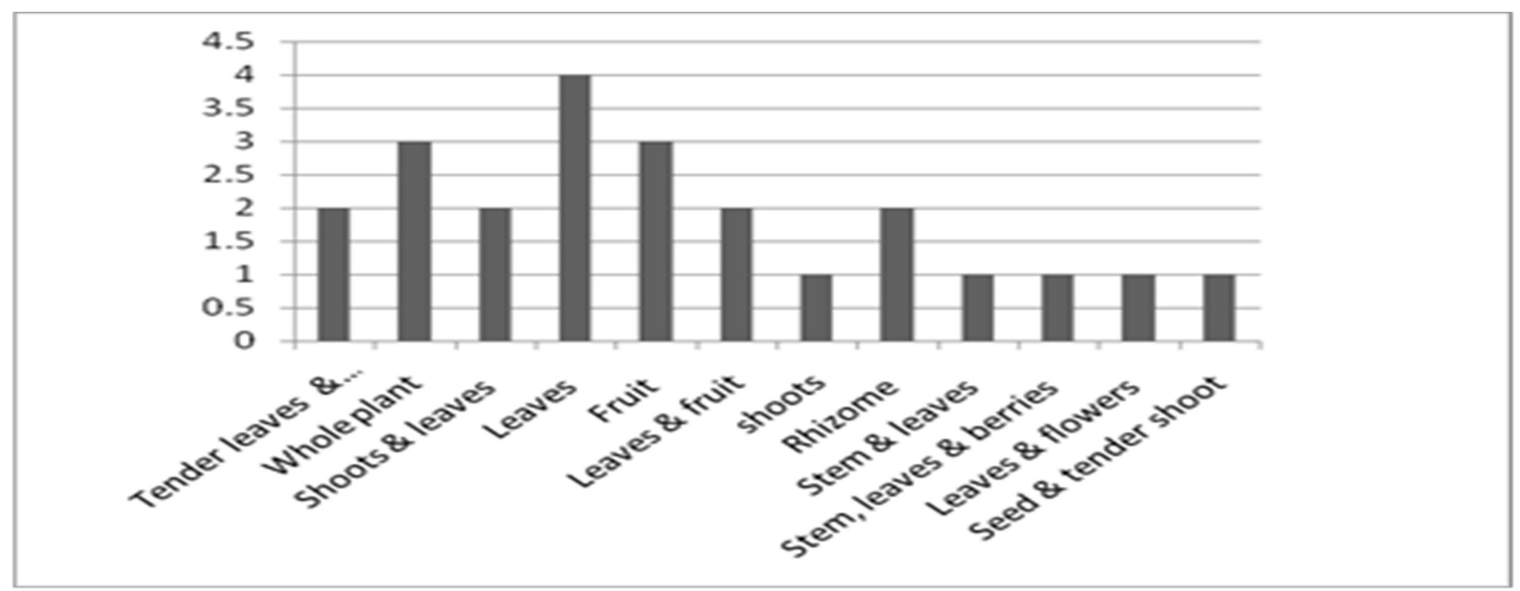

Figure 4: Graphical reprasentation of edible parts dominance in traditional vegetables

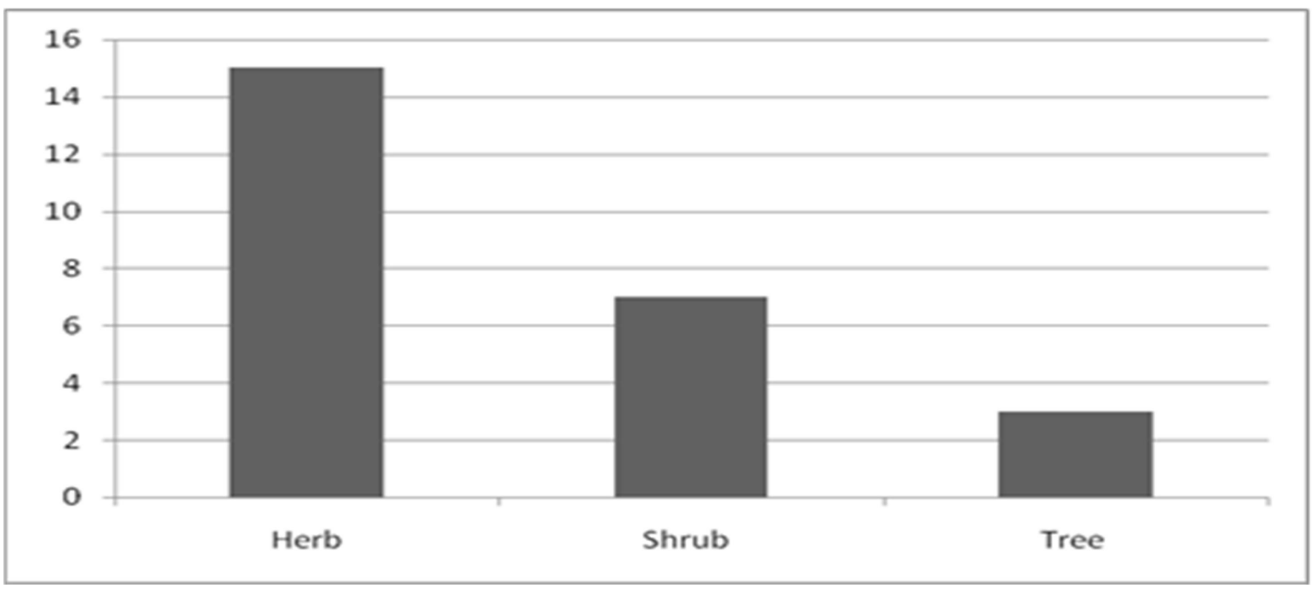

Figure 5: Graphical reprasentation of growth habit dominance in traditional vegetables

\section{Conclusion}

The current exploration concluded that only a division of conventional comprehension of local plants used by the people (Adi community) of East Siang district of Arunachal Pradesh. It was observed that the villages of the district rich in natural vegetables species of equally foodstuff and the rapeutic aspects. Through out investigation it was observed that villagers have their own local remedial familiarity of using plant based conventional medication for treating frequent ailments but such knowledge seems to be declining as majority of the villager's could not proper identify traditional plants which are existing by their society forest field. Such decline traditional knowledge could be due to the rising in clination towards modern medicine as well as lack of the script to documentation the information past centuries. Such related decline of traditional knowledge associated to classification and use of edible plants has been reported by earlier reasrchers. A detailed and good quality research is needed especially on nutritional aspects for understanding and documentation of indigenous knowledge acquire by the community people and its cultural association. It is aslo essential to conserve the language as well as habitual life fashion to promote the tribal awareness for generation to generation.

\section{Acknowledgement}

The authors are thankful to College of Horticulture and Forestry, Central Agricultural University, Pasighat-791102, Arunachal Pradesh, India for proper investigation. The authors are also thankful to Toto Tamut, Jopi and Oying Jamoh for logistic support during the field survey. 


\section{References}

Agarwal, K.C. (1999). Biodiversity.Agro-botanical publishers, Bikaner, 144.

Burhingame, B. (2000). Comparison of Total Lipids, Fatty Acids, Sugars and Non Volatile Organic Acids in Nuts from. Castanea, 99-100.

Deb, D. B., \& Dutta, R. M. (1971). Contribution to the flora of Tirap Frontier Division, India. Bombay Natur Hist Soc J.

Dhar, O. N., \& Nandargi, S. (2004). Rainfall distribution over the Arunachal Pradesh Himalayas. Weather, 59(6), 155157.

Gemedo-Dalle, T., Maass, B. L., \& Isselstein, J. (2005). Plant biodiversity and ethnobotany of Borana pastoralists in southern Oromia, Ethiopia. Economic Botany, 59(1), 4365 .

Grivetti, L. E., \& Ogle, B. M. (2000). Value of traditional foods in meeting macro-and micronutrient needs: the wild plant connection. Nutrition research reviews, 13(1), 31-46.

Haridasan, K., \& Rao, R. R. (1985). Forest flora of Meghalaya. Dehra Dun India.

Hooker, J.D. (1872-97). Flora of British India, Vol IVII.International Book Distributors, Dehradun.
Jain, S.K. \& Rao, R.R. (1977). A handbook of field and Herbarium methods. Today \& Tomorrow's Publishers, New Delhi.

Kanjilal, U. N., Kanjilal, P. C., \& Das, A. (1934). 1940. Flora of Assam, vol. I-IV. Calcutta: Government of Assam.

Modi, M. (2007). The Millangs. Himalayan Publishers, Itanagar \& New Delhi

Pandey, A.K. (2008).Underutilized vegetable crops.Satish Series Publishing House, Azadpur, Delhi, p. 366.

Panigrahi, G., \& Joseph, J. (1966). A Botanical tour to Tirap Frontier Division, NEFA (India). Nelumbo-The Bulletin of the Botanical Survey of India, 8(2), 142-157.

Sarmah, R. (2010). Commonly used non-timber forest products (NTFPs) by the Lisu tribe in Changlang district of Arunachal Pradesh, India. Sibsagar college teachers research journal, 5, 68-77.

Srivastava, R. C. (2009). Traditional knowledge of Adi tribe of Arunachal Pradesh on plants.

Sundriyal, M., \& Sundriyal, R. C. (2004). Wild edible plants of the Sikkim Himalaya: Nutritive values of selected species. Economic Botany, 58(2), 286-299. 